\title{
Metode Algoritma SIFT dan Histogram Color RGB Untuk Analisis Manipulasi Copy-Move pada Citra Digital \\ Muhamad Masjun Efendi ${ }^{1}$, Rosidin², Erfan Wahyudi ${ }^{3}$ STMIK Mataram ${ }^{1,3}$ \\ Universitas Nahdatul Ulama Cirebon² creativepio@gmail.com ${ }^{1}$
}

\begin{abstract}
Abstrak - Dengan kecanggihan teknologi sekarang ini menyebabkan citra digital dengan mudah dapat dimanipulasi. Manipulasi gambar dilakukan dengan cara menambahkan atau menghapus beberapa elemen dari gambar yang menghasilkan sejumlah pemalsuan citra yang tidak dapat diperhatikan oleh mata manusia. Hal ini juga didukung dengan tersedianya software editing gambar yang mudah digunkan, sehingga semua orang bisa melakukan manipulasi citra. Pemalsuan citra copy-move adalah jenis pemalsuan citra yang paling umum digunakan karena tekniknya yang mudah dilakukan oleh banyak orang dengan cara bagian dari gambar itu sendiri disalin dan disisipkan ke bagian lain dari gambar yang sama.

Penerapan Algoritma SIFT (Scale Invariant feature tranform) dan histogram warna RGB pada Matlab dapat mendeteksi kecocokan objek pada citra digital dan melakukan pengujian secara akurat. Pada penelitian ini membahas tentang implementasi untuk mendapatkan kecocokan objek pada citra digital yang sudah dimanipulasi menggunakan metode Algoritma SIFT pada source Matlab, yaitu dengan membandingkan citra yang asli dengan citra yang sudah dimanipulasi. Kecocokan objek pada citra digital didapat dari banyaknya jumlah keypoint yang didapat, parameter tambahan lainnya yaitu membandingkan jumlah piksel pada citra yang dianalisa, serta perubahan histogram pada warna RGB pada masing-masing citra yang sudah dianalisa.
\end{abstract}

Kata Kunci - citra, sift, keypoint, histogram, rgb, copy-move

\section{Pendahuluan}

Pengolahan image pada citra digital dapat dengan mudah dibuat, diedit dan dimanipulasi tanpa meninggalkan petunjuk visual oleh penggunanya, seperti aplikasi gimp dan adobe photoshop contoh nya, yang dengan begitu mudah nya keaslian image dapat diubah / dimanipulasi. Kemampuan ini tentunya juga dapat

disalahgunakan untuk merusak kredibilitas keaslian image dalam berbagai aspek, sehingga dapat dilakukan sebagai tindakan kejahatan, perubahan image pada citra digital dapat menyampaikan informasi yang berbeda dengan image pada citra digital aslinya. Pelaku kejahatan berupaya untuk memanipulasi image untuk keuntungan mereka sendiri.Terbentuknya suatu image pada citra digital didapat dari beberapa kombinasi pikselnya. Untuk mendapatkan image yang sudah diubah, diperlukan beberapa tahap dalam melakukan proses forensik citra digital. Didalam nya terdapat beberapa perubahan dari aslinya pada setiap nilai pikselnya (Pratama, 2014).

Teknologi Digital khususnya image, telah menjadi teknologi utama untuk menciptakan, memproses, mentransmisikan dan menyimpan informasi berupa pengetahuan dan aset intelektual. Pengetahuan multidimensional dan aset intelektual diproduksi dan diwakili dalam berbagai bentuk seperti audio, video, teks, gambar, jika dikelompokkan, kita dapat menyebutnya sebagai bentuk multimedia. Akhirnya semua bentuk disimpan sebagai bentuk digital dan bentuk byte yaitu konten digital. Image pada Citra digital banyak digunakan di masyarakat kita. Dari surat kabar ke majalah, jurnal ilmiah, dokter di bidang medis, industry mode, ruang pengadilan dan sebagainya sangat bergantung pada image digital. Integritas informasi sangat mendasar di berbagai bidang. Teknologi digital saat ini mulai mengikis kepercayaan. Meskipun kasus manipulasi merusak fotolimage bukanlah hal yang baru, selama beberapa tahun terakhir, image yang dirusak muncul dengan frekuensi dan kecanggihan, pengembangan perangkat lunak pengolah image digital yang semakin canggih ini, telah menjadi mudah untuk membuat pemalsuan image dari satu atau beberapa image tanpa meninggalkan petunjuk yang jelas. Kejahatan digital tumbuh pada tingkat sangat pesat. Kejahatan ini telah menyebabkan banyak masalah, termasuk masalah hukum dan etika.

Pemalsuan image pada citra digital banyak dilakukan melalui pendekatan secara pasif. Salah satu metode pendekatan secara pasif yang popular, yaitu melakukan manipulasi dengan cara teknik copy-move. Pemalsuan image pada citra digital dengan cara suatu image disalin kemudian disisipkan ke bagian citra yang lain. Pemalsuan image copy-move dilakukan untuk 
menyembunyikan rincian tertentu atau untuk menduplikasi objek dalam suatu citra. Karena pemalsuan tersebut dilakukan dalam satu image, maka wilayah yang rusak hampir sama, sifat citra yang asli akan sulit diidentifikasi oleh manusia. (Salma Amtullah, Dr. Ajay Koul, 2014).

Dengan adanya bidang ilmu Forensik citra digital, akan membantu para penegak hukum, intelijen, investigasi swasta, dan media. Semakin majunya teknologi image pada saat ini mengangkat isu-isu baru dan tantangan dalam menentukan keaslian image pada citra digital. Forensik citra digital merupakan salah satu metode ilmiah pada bidang penelitian yang bertujuan untuk mendapatkan fakta-fakta pembuktian dalam menentukan keaslian image pada citra digital. Pada tulisan ini dijelaskan dalam menganalisa suatu image pada citra digital pada aplikasi matlab menggunakan Algoritma SIFT (Scale Invariant feature tranform), untuk menggunakan aplikasi tersebut, diharapkan dapat menghasilkan analisa image yang lebih baik.

Algoritma SIFT (Scale Invariant feature tranform) adalah algoritma dalam visi komputer untuk mendeteksi dan menggambarkan fitur lokal pada image. Algoritma ini dipatenkan di Kanada oleh University of British Columbia dan diterbitkan oleh David Lowe pada tahun 1999. Algoritma ini dapat melakukan pengenalan objek, pemetaan robot dan navigasi, image stitching, pemodelan 3D, pengenalan isyarat, pelacakan video, mengidentifikasi satwa liar (Lowe, 1999). Pada penelitian yang lain, Algoritma SIFT adalah (Scale Invariant Feature Transform) yang digunakan untuk mencocokkan gambar berdasarkan fitur keypoin utama (invarian skala dan rotasi). Algoritma SIFT adalah salah satu metode ekstraksi fitur yang paling banyak digunakan. Algoritma Sift digunakan untuk menemukan titiktitik kunci pada image, dalam metode ini termasuk deskripsi sift dan SIFT deskriptor (Anantharaj, 2014). Dengan banyaknya kasus kejahatan terhadap manipulasi image, diharapkan metode yang peneliti gunakan, dapat

menganalisa image pada citra digital sehingga dapat mendeteksi image yang sudah dirubah dari citra digital aslinya.

Penelitian tentang metode ganda yang digunakan pada image pada citra digital memiliki tujuan, diantaranya:

1. Menerapkan Algoritma SIFT (Scale Invariant feature tranform) dan histogram warna RGB dengan menggunakan aplikasi Matlab untuk dapat mendeteksi kecocokan objek pada citra digital.

2. Melakukan pengujian keakuratan yang lebih baik dalam menganalisa image pada citra digital yang sudah diubah dari aslinya.

\section{Metode Penelitian}

a. Studi Pustaka

Penelitian ini dilakukan dengan melakukan studi kepustakaan, dengan mengumpulkan beberapa bahan referensi yang terkait dengan penelitian, baik melalui buku, artikel, paper, jurnal, makalah, dan mengunjungi beberapa situs yang terdapat pada internet terkait dengan image forensik, citra digital, deteksi keaslian image, algoritma processing image, forgery image, copy move, tampering image, citra digital, rotation, scala, keypoint khususnya algoritma yang dapat mendeteksi kecocokan objek pada citra digital.

\section{b. Persiapan Alat dan Bahan Penelitian}

Tahapan ini melakukan persiapan tools yang digunakan dalam melakukan analisis pendeteksi kecocokan image menggunakan MATLAB. Image yang didapat dari hasil kamera dan internet di olah menggunakan Photoshop.

\section{c. Pengembangan Sistem}

Membangun sistem untuk mendeteksi kecocokan objek pada citra digital, menggunakan Algoritma SIFT, dengan mencari dan mencocokan keypoint yang didapat pada image yang akan dianalisis.

\section{d. Implementasi Sistem}

Implementasi adalah proses untuk menggunakan metode algoritma SIFT sebagai dasar untuk mendeteksi kecocokan objek pada citra digital, yang diharapkan digunakan untuk mempermudah user / pengguna, dalam hal ini adalah investigator.

\section{e. Hasil dan Pembahasan}

Pada tahapan ini dilakukan dengan tujuan untuk mepresentasikan hasil dan pembahasan dari hasil yang sudah dicapai dari metode yang sudah diterapkan.

f. Analisis Hasil

Untuk mengetahui keberhasilan dalam menerapkan metode Algoritma SIFT yang digunakan.

\section{g. Kesimpulan}

Tahapan akhir yaitu penyampaian kesimpulan atas hasil dari penelitian ini.

\section{Hasil dan Pembahasan}

Pada penelitiaan ini menggunakan aplikasi matlab dengan metode Algoritma SIFT, dengan memanggil fungsi yang sudah dibuat pada file matlab. Implementasi inputan data yang akan diproses berupa dua file sampel image dengan format JPG/JPEG, sumber image didapat dari hasil kamera Smartphome EverCoss R40A, 
Smartphone Xiaomi Redmi 4 dan beberapa sampel image yang didapat dari internet. Dengan melakukan proses beberapa tahapan dan fungsi yang ada di kode matlab tersebut, dilakukan compile dan running dari aplikasi yang menghasilkan keypoint skala dan rotasi sehingga dapat berfungsi untuk mencari kecocokan keypoint yang sama pada masing-masing image.

Untuk melalukan pengujian ini, penulis menggunakan aplikasi matlab, yang sudah disiapkan source code nya untuk mendeteksi kecocokan objek pada citra digital menggunakan Algoritma SIFT. Pada tabel 1 dan 2 berikut ini adalah sampel data image asli dan image yang sudah dimanipulasi. File - file tersebut sudah diolah menggunakan photohop CS6, yang disimpan dalam format JPG/JPEG, image-image tersebut diantaranya adalah: dian_sastr wardoyo, sampel, dian_edit, cover_film, agus, agus_oci, bertiga, cewek , cewek_méka, coba1, cover_film, dede_nagita, dian_edit, Image_01, image_01_original, insan_syahrini, jokowi_mark, jokowi_mark_edit, menara_eifel_paris, oci_malay, oci_paris, oshi, sampel, sampel1, trio, dede_nagita_palsu,dian_sastro, dian_sastro1, oshi_agus, dll. Metode Algoritma SIFT yang digunakan adalah fungsi yang dapat membaca dua image, menemukan fitur SIFT mereka, danmenampilkan garis yang menghubungkan keypoint yang cocok.

Persamaan yang didapat pada image pertama hanya jika jaraknya kurang dari rasio kali jarak ke arah persamaan terdekat pada image kedua, kemudian mengembalikan jumlah kecocokan yang ditampilkan. Cara kerja Algoritma pada aplikasi ini adalah, setelah melakukan inputan dari dua image, tahap awal mencari keypoint pada tiap - tiap image, nilai konstanta di buat pada jarak rasio 0,6, ini dilakukan dengan harapan, cara kerja analisis dari matlab menjadi lebih ringan, descriptor pada image pertama, dicocokkan dengan deskriptor pada image kedua, matriks - matriks pada setiap image dihitung ulang, menghitung vektor pata setiap titik sudut, mengambil nilai inverse cosine dan menampilkan hasilnya, selain mendapatkan keypoint, parameter tambahan lain nya yaitu mendapatkan nilai piksel untuk memperkuat analisis dari image yang diteliti.

manipulasi dari internet tidak dilakukan proses manipulasi apapun dibiarkan sesuai dengan aslinya. Data inilah yang kemudian dijadikan sebagai sample kasus dalam penelitian ini. Hasilnya seperti yang dijabarkan pada tabel 1 dan tabel 2 berikut:

Tabel 1. Deteksi Kecocokkan Objek

\begin{tabular}{|c|c|c|}
\hline No & Citra Asli1 & Citra Asli2 \\
\hline
\end{tabular}

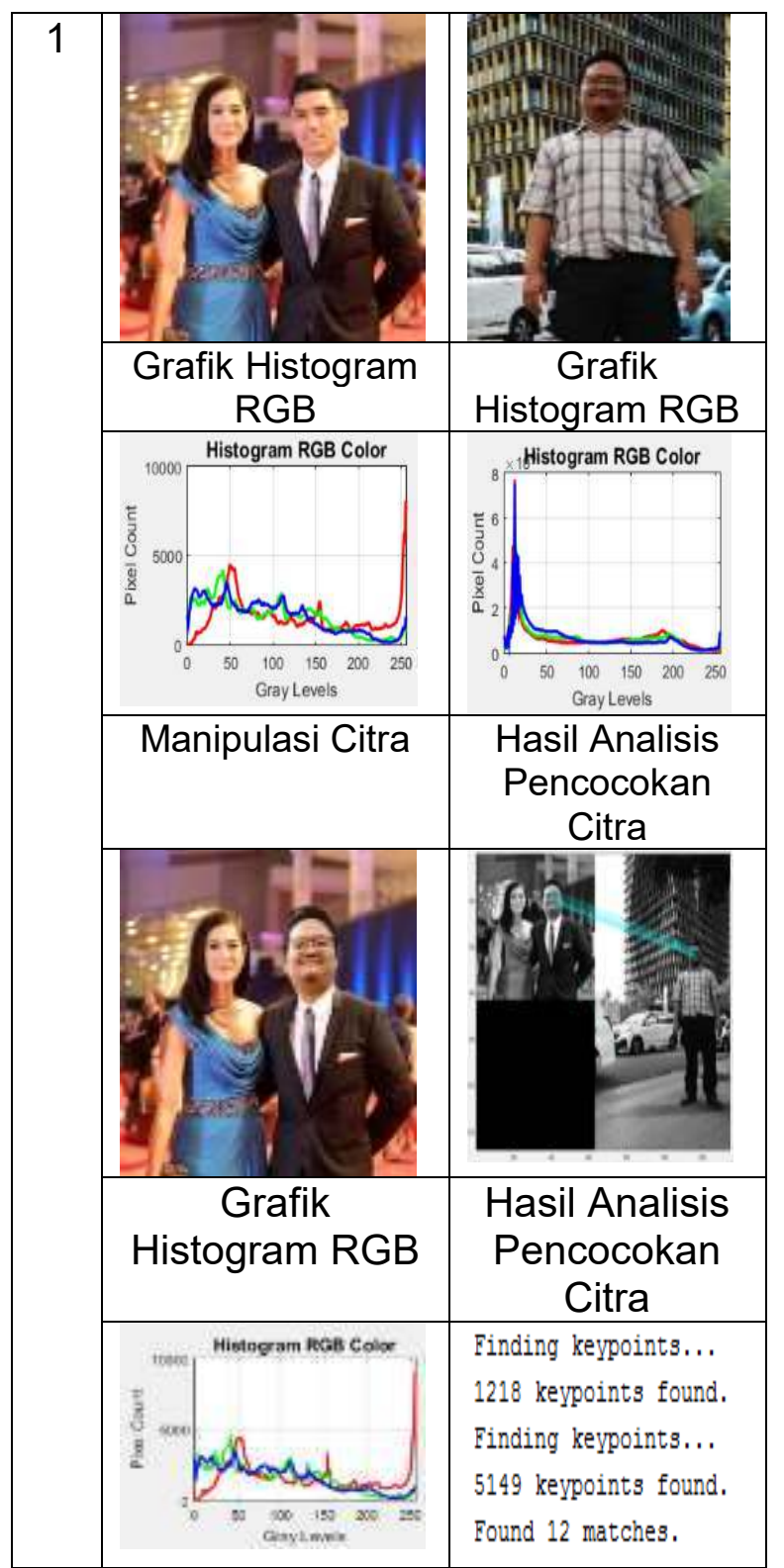


Lanjutan Tabel 1. Deteksi Kecocokkan Objek

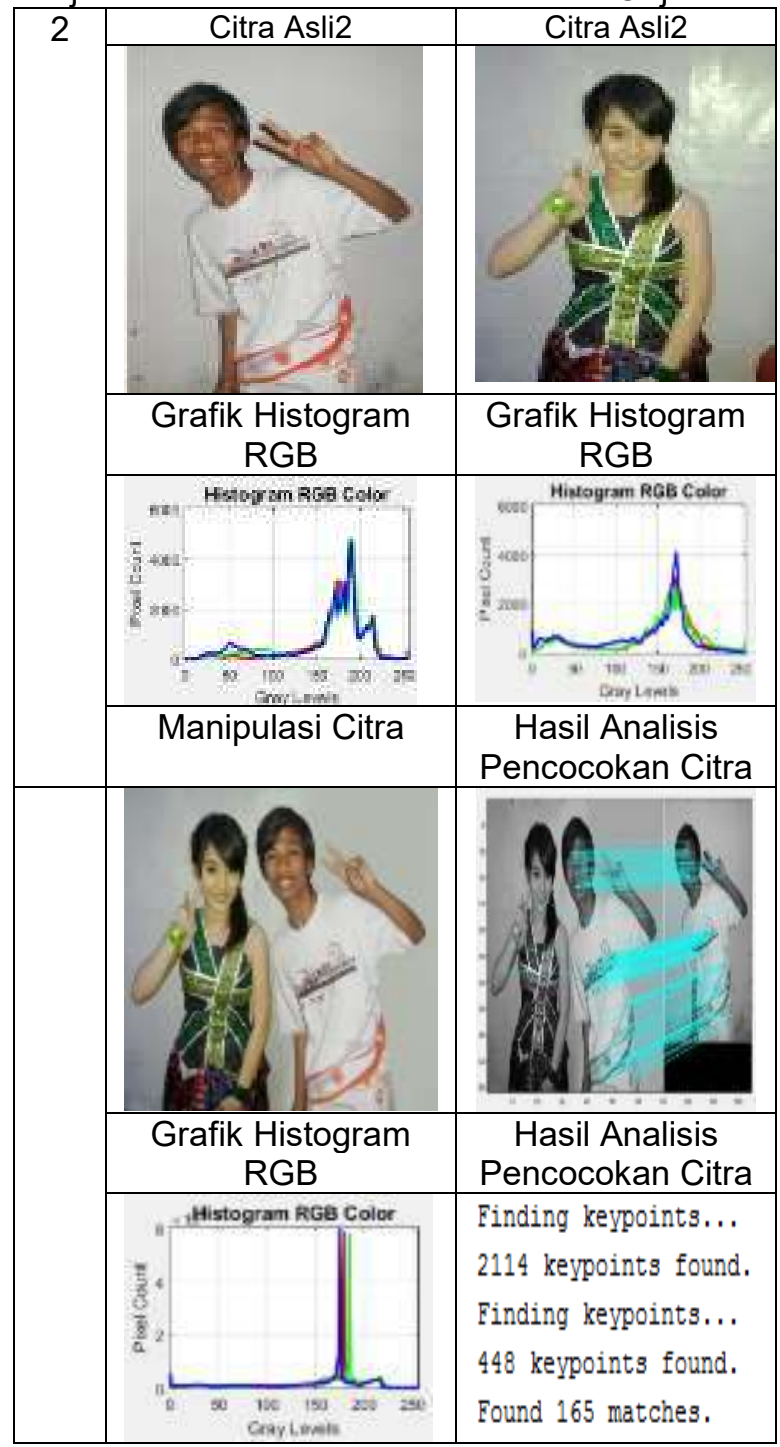

Pada tabel 1 dan tabel 2 merupakan Perbandingan tiga image yang dibandingkan menghasilkan nilai histogram dengan jumlah piksel yang berbeda-beda, artinya nilai histogram tersebut bisa dijadikan acuan sebagai parameter tambahan untuk melakukan pencocokan objek, kemudian jika dilihat dari jumlah keypoint nya, ada kecocokkan pada objek yang ditandai dengan garis.

Pada hasil pengujian pada metode Algoritma SIFT, dilakukan pada satu set dari 16 (enam belas) image dari 5 (lima) image yang asli, 5 (lima) yang telah dimanipulasi menggunakan photosop CS6, dan 6 (enam) image pembanding lainnya. Image ini dipilih secara acak dari hasil kamera Smartphome EverCoss R40A, Smartphone Xiaomi Redmi 4 dan beberapa sampel image dari internet. Resolusi image terletak pada kisaran piksel ke piksel. Image yang dimanipulasi adalah hasil potongan atau croping dari image yang juga mengandung persegi atau segi empat yang ditempa melalui penyisipan berupa rotasi, copymove, penskalaan (simetris atau asimetris) atau bahkan kombinasi dari ketiganya.

Penggunaan algoritma SIFT dipilih sebagai metode ekstraksi ciri karena metode ini invarian terhadap perubahan skala, rotasi, translasi, dan iluminasi. SIFT digunakan untuk memperoleh ciri dari pola keypoint yang didapatkan. Harapannya dengan menerapkan metode ini, dari keypoint yang didapat pada masing- masing image tersebut, mendapatkn kecocokan objek yang akurat. Tahap pertama dalam menentukan keypoint yang invarian terhadap perubahan skala pada image adalah mencari nilai ekstrim pada ruang skala. Untuk mendapatkan lokasi keypoint dalam suatu ruang skala secara efisien, digunakan fungsi Difference-of-Gaussian (DoG), nilai untuk fungsi DoG diperoleh dari selisih antara citra Gaussian dengan skala berbeda.

Setiap keypoint yang tidak tereliminasi akan diberikan orientasi sehingga tidak akan terpengaruh dengan adanya rotasi pada citra. Pada penelitian ini, fitur-fitur berupa lokasi keypoint dan juga vektor ciri dari keypoint tersebut telah didapatkan. Kemudian klasifikasi pun telah dilakukan, sehingga dapat disimpulkan bahw sistem ini mampu mendeteksi kecocokan objek pada citra digital secara akurat. Untuk memperkuat hasil analisa pada pengujian diatas, ditambahkan juga pengujian menggunakan grafik histogram warna RGB (Red, Green, Blue). Dimana tingkat perbedaan pada image bisa didapatkan dari perubahan jumlah piksel dan warna RGB yang ditampilkan berdasarkan grafik histogram.

\section{Kesimpulan}

Dari hasil penelitian dan pengujian yang telah dilakukan, maka menghasilkan kesimpulan sebagai berikut:

1. Penerapkan Algoritma SIFT (Scale Invariant Feature transform) dan histogram warna RGB dalam menentukan kesamaan letak keypoint dan jumlah piksel pada image, untuk mendapatkan kecocokan objek pada citra digital pada matlab berhasil diimplementasikan.

2. Berdasarkan hasil pengujian didapatkan keakuratan dalam mengidentifikasi image pada citra digital menggunalan Algoritma SIFT (Scale Invarian Feature Transform), bahwa penelitian telah berjalan baik dan lancar.

\section{Daftar Pustaka}

Pratama, A. R. 2014. Digital Evidence.

Lowe, D.G. 1999. Object Recognition from Local Scale-Invariant Features, Canada, pp. 1,2,3. Amtullah, S., \& Koul, A. 2014. Passive Image Forensic Method to detect Copy Move Forgery in Digital Images, pp 96-104. 
Sutoyo, T, dkk. 2009, "Teori Pengolahan Citra Digital", Penerbit Andi, Yogyakarta.

Putra, D. 2010, "Pengolahan Citra Digital", Penerbit Andi, Yogyakarta. 